\title{
Preliminary Overview of Several Capital Relocations in Relationship with a Plan of Indonesian Capital Relocation
}

\author{
Abd Muluk bin Abd Manan ${ }^{1, a)}$ \& Hitapriya Suprayitno ${ }^{2, b)}$ \\ ${ }^{1)}$ Dept. of Architecture and Sustainable Design, Universiti Tunku Abdul Rahman (UTAR), Kuala \\ Lumpur, Malaysia. \\ ${ }^{2)}$ Civil Engineering Dept., Institut Teknologi Sepuluh Nopember (ITS), Surabaya, Indonesia.
}

Corespondance : ${ }^{a}$ abdmuluk@utar.edu.my \& ${ }^{b}$ suprayitno.hita@gmail.com

\begin{abstract}
A plan to move the Indonesian capital from Jakarta to Kalimantan island has been decided. Socialization of this program has been done by the government. A contest for the urban capital plan has been organized. But the Basic Systematic Reflection on Capital Relocation has never been developed among the academician. This development should be started by observing Capital Relocation Experiences. Six capital relocations have been observed. The research indicates that relocate the national capital to a new location is not something uncommon or inappropriate. The majority reasons for the capital relocation are the old capital is already too dense, to balancing the development, or certain military reason. In general, the success of relocation is having a more appropriate capital city with a desired and controlled density. While, the general failure of capital relocation is uncontrolled development, thus becoming a dense city.
\end{abstract}

Keywords: infrastructure \& facility management, capital relocation.

\section{INTRODUCTION}

Indonesia has a plan to move its capital from Jakarta to Kalimantan. The location of the new capital has been defined in Kecamatan Sepaku, Kabupaten Penajam Paser Utara, Kalimantan Timur Province. This is located on the north of the northern tip of Balikpapan Bay, north of Balikpapan City. Socialization for capital relocation has been done to important universities. New Capital Urban Plan contest has been organized, and already generated a winner. Capital relocation is a huge work, need a good reflection and planning. Basic Systematic Reflection needs to be developed by the scientific community.

A deep and thorough reflection must be executed upon the area designated for the new capital city. The area must be well planned and designed to be able to support the capital city well. The area must be furnished with appropriate infrastructure and facilities. What are the basic considerations for this context?

The new capital must be well thought and planned. The new capital needs enormous infrastructures and facilities which must be well planned and organized. Meanwhile, in the former capital, suddenly there are a lot of government facilities that must be abandoned. A good Infrastructure and Facility Asset Management in the stage of planning and liquidation need to be well organized (Soemitro \& Suprayitno, 2018; Suprayitno \& Soemitro, 2018).

It can be seen clearly that Reflection on Capital Relocation is very complex. Scientifically, a Basic Systematic Reflection on capital relocation needs to be developed. To develop a Basic Systematic Reflection need to be started with developing an Overview of Capital Relocation. This overview can serve as a base for developing the Basic Systematic Reflection. A lot of capital relocations have been done. As a Preliminary Overview, several basic questions can be posed: The reason to move the capital? The removal of different country 
functions: executive, legislative, judicative, embassy, education, military? The result: success or failure?

This paper presents research results in revealing several capital relocations, especially in terms of reason, success, and failure aspects.

\section{RESEARCH METHOD}

The objective of this research is to reveal and identify the important principal facts about national capital relocation. These important principal facts cover the reason for relocation, the success, and the failure of relocation. In this preliminary research, all of the data collected are secondary data, added by some interviews to the knowing persons The data collected are data on a list of relocated capital, an overview of several relocated capital data, and finished by analyzing.

\section{PRELIMINARY OVERVIEW}

\section{Discussion Systematic}

The overview is organized by started with a very brief overview of the Indonesian Capital Relocation Plan, and then continued by identification of several nation capital relocations, followed by a brief desk overview of several different national capital relocations, and finished by a brief synthesis.

\section{Brief Overview of Indonesian Capital Relocation Plan}

The Indonesian capital is planned to be relocated to East Kalimantan Province. The site for the new capital is located in Kecamatan Sepaku, Kabupaten Penajam Paser Utara, East Kalimantan Province. The area is located north of Balikpapan City, right on the north of the northern end of Balikpapan Bay. Samarinda City, as the capital of East Kalimantan Province, is located $95 \mathrm{~km}$, north of Balikpapan City, it is around $75 \mathrm{~km}$ north of the new capital. The new capital is planned to accommodate, basically, the executive, the legislative, the judicative, and the diplomatic offices. The location is presented in the following Figure 1.

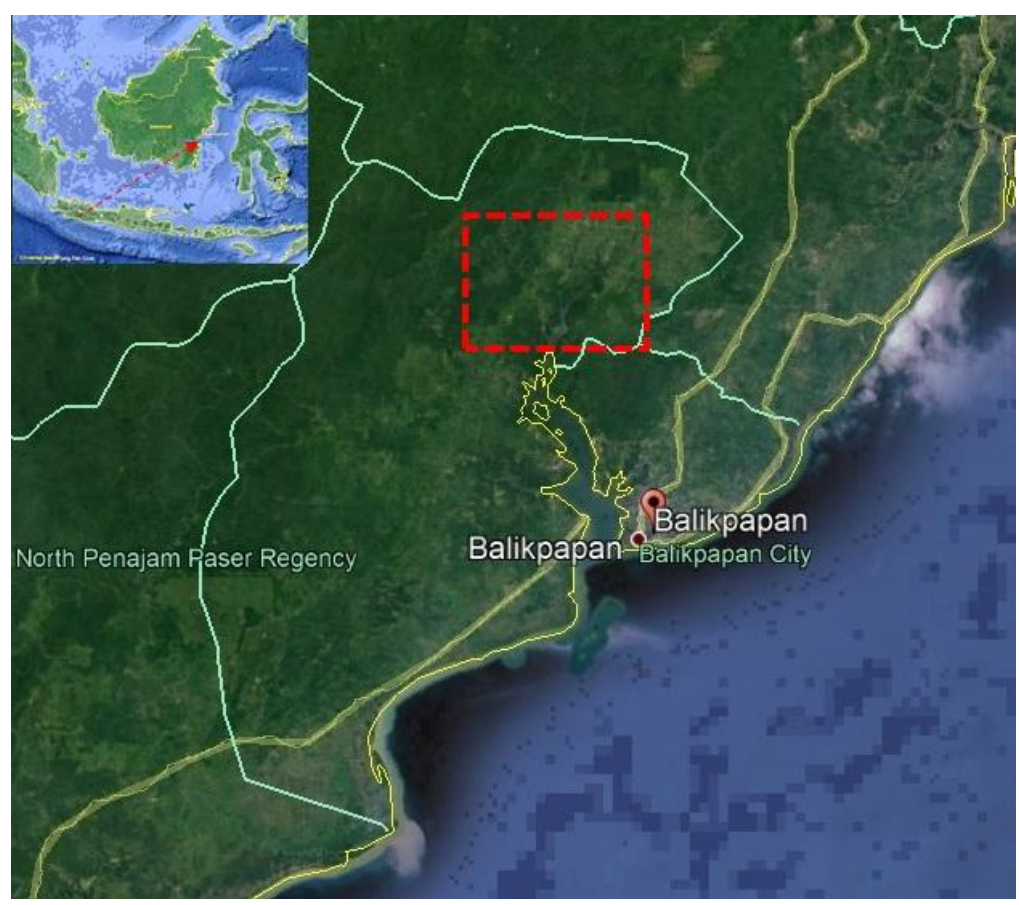

Figure 1. Indonesian Capital Relocation Location Map. 
The area designated for the new capital is still a forest, with rolling to hilly terrain, and several rivers flow tortoise in the area. As a new capital city, the city must function well as an administrative city. Therefore, the capital must mainly well be connected for the person and light cargo transportation and not for heavy cargo transportation, and also must be well connected for telecommunication. Realizing the transportation and telecommunication needed is not difficult. Balikpapan - Samarinda Toll Road is about to be finished, and the connection to New Capital has been prepared (Anonim, 2019; Anonim, 2020). A cable-stay bridge over Balikpapan Bay, over Balang Island, is still under construction. This bridge will improve a lot the road connection between South Kalimantan Province and East Kalimantan Province (Anonim, 2020; Elena, 2019). The closest airports are Sultan Aji Muhammad Sulaiman Sepinggan Airport in Balikpapan and APT Pranoto Airport in Samarinda (Anonim, 2020; Wikipedia Indonesia 2020). Seven Higher Education institutions can be found in Balikpapan and Samarinda, as the closest cities to the New Capital, these consist of 4 polytechnics, 1 state Muslim religion institute, 1 institute of technology and 1 university. These three publics of not vocational higher education are Mulawarman University in Samarinda, IAIN Samarinda in Samarinda, and Institute of Technology Kalimantan in Balikpapan (Wikipedia Indonesia, 2020a). Urban Plan Contest for the new capital has been organized, the winner is Studio Urban+, with a title of "Nagara Rimba Nusa" (Ardiyanto, 2020).

\section{Several Examples of Capital Relocations}

Relocations of the national capital have been done in several countries since the existence of the first country as a kingdom, a long time ago. Japan's capital has been moved from Asuka, Fujiwara, Nara, Kyoto, and finally to Edo, in which its name was changed to become Tokyo in 1868. The capital of Canada has been moved, back and forth, between Quebec and Toronto, and finally was relocated to Ottawa in 1857, at the time of British territory, until the present. Thailand's capital has been relocated among Sukothai, Ayutthaya, and Thonburi, and finally was relocated to Bangkok in 1782. The USA capital was moved from among Philadelphia, Baltimore, Lancaster, York, Princeton, New York, Annapolis, Trenton, and finally to Washington in 1800 until now (Klein, 2018; Sawe, 2019; Wikipedia, 2020; Wikipedia, 2020a; Wikipedia, 2020b).

These capital relocations are continued in the $20^{\text {th }}$ and 21 st centuries. The recent capital relocations, of course, are much more complicated than the ancient capital relocations. Therefore, it is important to observe and try to understand the phenomena, scientifically. Examples of recent capital relocations are presented in the following Table 1.

Table 1. Examples of Nation Capital Relocations

\begin{tabular}{cllll}
\hline \multirow{2}{*}{ No } & \multirow{2}{*}{ Country } & \multicolumn{2}{c}{ Capital } & \multirow{2}{*}{ Year } \\
\cline { 3 - 4 } & Old & New & 1912 \\
2 & India & Calcutta & New Delhi & 1913 \\
2 & Australia & Sydney & Canberra & 1918 \\
3 & Rusia & St. Petersburg & Moscow & 1923 \\
4 & Turkey & Istambul & Ankara & 1955 \\
5 & Pakistan & Karachi & Islamabad & 1960 \\
6 & Brazil & Rio de Janeiro & Brasilia & 1980 \\
7 & Tanzania & Dar es Salam & Dodoma & 1991 \\
8 & Nigeria & Lagos & Abijan & 1995 \\
9 & Malaysia & Kuala Lumpur & Putrajaya & 1997 \\
10 & Kazaksthan & Almaty & Nur-Sultan & 2006 \\
11 & Myanmar & Yangoon & Naypiydew & \\
\hline
\end{tabular}

source : Augesti, 2019; Wikipedia,2020. 


\section{New Delhi (India)}

India's British occupiers decided to shift the capital in 1911 from Calcutta to Delhi, where they set up a temporary seat of government the following year. Two leading architects, Edward Lutyens and Herbert Baker took 20 years to build imposing government buildings, bungalows, and avenues in the south of what is now called "Old Delhi." The capital city of British India -which was renamed New Delhi in 1927 -- was formally inaugurated in 1931. The departure of the British in September 1947 left the country divided into India and Pakistan. In the aftermath, 350,000 Muslims fled Delhi for Pakistan, while 500,000 non-Muslims arrived in the city in 1947 alone. It was labeled "history greatest migration". It was also a scale of transformation for which the city was entirely unprepared (McKinzey 2001; Wikipedia, 2020c).

A half-century earlier, when it became the capital of the British Raj, Edwin Lutyens arrived as the chief architect of the Delhi town planning committee. Over two months, he assessed the city and reshape Delhi in his image of a "proper European capital" - wide avenues, axial vistas, parks, and roundabouts, just like his beloved Champs-Élysées. Lutyens' portion of the city became known as New Delhi. The Ford Foundation committee similarly sought to reconstruct the city anew. Delhi was to become the model of development for India. The masterplan was Nehru's showpiece (Wikipedia, 2020c).

On paper, the masterplan is a high modernist dream. Six "ring towns" grow from Delhi's periphery, each with its own economic, social, and cultural ties with the central city. Under the guidance of the Delhi Development Authority (DDA), each town should hit its targets for population, manufacturing, and employment for each of the next 30 years of urban growth. Moreover, they would be beautiful and should pervade the design of all public and private buildings: modern industrial buildings in attractively landscaped grounds, pleasing shopping centers, simple and beautifully designed schools and homes (Wikipedia, 2020c).

This was a social vision as much as an architectural one. The city was to incorporate all the languages and all the regions of India. For Delhi's planners, the key to implement this vision was centralization. Until then, Delhi had evolved haphazardly, more often than not without the benefit of planning development in the public interest. Private interests run rampant, overlooking, or not being concerned with the efficiencies and facilities that are required (Mohan, 1985).

\section{The Reason}

Among reasons to relocate the capital was its position in India's north, which made it more convenient for the British to govern the territories they held. Colonial rule was also facing immense opposition in Calcutta, a literary center where the nationalist movement was growing daily, with calls to boycott British goods and bombings of officials. Calcutta was the capital of India during the British Raj, until December 1911. Calcutta had become the center of the nationalist movements since the late nineteenth century, which led to the partition of Bengal by then Viceroy of British India, Lord Curzon. This created massive political and religious upsurge including political assassinations of British officials in Calcutta. The anti-colonial sentiments amongst the public led to a complete boycott of British goods, which forced the colonial government to reunite Bengal and immediately shift the capital to New Delhi (McKinzey, 2001; Wikipedia, 2020c).

Old Delhi had served as the political and financial center of several empires of ancient India and the Delhi Sultanate, most notably of the Mughal Empire from 1649 to 1857. During the early 1900s, a proposal was made to the British administration to shift the capital of the British Indian Empire, from Calcutta on the east coast, to Delhi. The Government of British India felt that it would be logistically easier to administer India from Delhi, which is in the center of northern India. The land for building the new city of Delhi was acquired under the Land Acquisition Act 1894. During the Delhi Durbar on 12 December 1911, George V, then 
Emperor of India, announced that the capital of the Raj was to be shifted from Calcutta to Delhi, as laying the foundation stone for the viceroy's residence in the Coronation Park, Kingsway Camp (Wikipedia, 2020c).

Large parts of New Delhi were planned by Edwin Lutyens and Herbert Baker, both leading 20th-century British architects. The contract was given to Sobha Singh. The original plan called for its construction in Tughlaqabad, inside the Tughlaqabad Fort, but this was given up because of the Delhi-Calcutta trunk line that passed through the fort. Construction began after World War I and was completed by 1931. The city that was later dubbed "Lutyens' Delhi" was inaugurated in ceremonies beginning on 10 February 1931 by Lord Irwin, the Viceroy. Lutyens designed the central administrative area of the city as a testament to Britain's imperial aspirations (Wikipedia, 2020c).

\section{The City Today}

New Delhi is an urban district in the city of Delhi. New Delhi is located inside the National Capital Territory of Delhi. It covers an area of $42.7 \mathrm{~km} 2$, with an elevation of $216 \mathrm{~m}$. In the year 2011, its population was counted at 257.803 persons, very few. But, the Metropolitan Delhi - New Delhi, in 2006, had a population of $26,454,000$ persons. It is quite a big metropolitan area (Wikipedia, 2020c).

With a climate classified as semi-arid, the.annual temperature is around $.25{ }^{\circ} \mathrm{C}$, with the daily temperature varies around $14-34{ }^{\circ} \mathrm{C}$. New Delhi lies in several fault lines, therefore light earthquake is common there (Wikipedia 2020c).

In terms of transportation, New Delhi is equipped with a good transportation system. The Indira Gandhi International Airport is located southwest of Delhi. It is considered the best airport of 15-25 million passengers/year, in 2010. New Delhi is connected with good Toll Roads and National Roads. Delhi is a place for the major junction of the Indian Railway Network. It is facilitated by 5 train stations: New Delhi station, Old Delhi station, and 3 others. Headquarter of Northern Delhi Railway is located in Delhi. Urban public transport is also well developed, it served by Delhi Metro - of 6 lines and still being developed, Bus Rapid Transit, and paratransit (Wikipedia, 2020c).

As the size of the Metropolitan Area of 26 million inhabitants, New Delhi is considered as the most polluted city for air pollution. In 2017, the Indian Medical Association stated that the Metropolitan is in a public health emergency, due to air pollution. New Delhi Municipal Council instore a restriction on diesel cars, and a taxi must use the CNG: Compressed natural gas (Wikipedia, 2020c).

New Delhi continued to be the seat of government after the British left India in 1947, housing the country's Parliament, the top court, and various ministries. Now its population is nearly 20 million as compared to about 400,000 in 1911, with people from all parts of the country migrating to the city in search of a better life. It is now the largest commercial city in northern India. It has an estimated second highest per capita income in India after Goa. Connaught Place, one of North India's largest commercial and financial centers, is located in the northern part of New Delhi. Adjoining areas such as Barakhamba Road, ITO are also major commercial centers (McKinzey, 2001; Wikipedia 2020c)

The government and quasi-government sector were the primary employers in New Delhi. The city's service sector has expanded due in part to the large skilled English-speaking workforce that has attracted many multinational companies. Key service industries include information technology, telecommunications, hotels, banking, media, and tourism. The 2011 World Wealth Report ranks economic activity in New Delhi at 39, but overall, the capital is ranked at 37, above cities like Jakarta and Johannesburg. New Delhi with Beijing shares the top position as the most targeted emerging markets retail destination among Asia-Pacific markets (McKinzey, 2001; Wikipedia, 2020c). 
The DDA took over the sole responsibility of directing Delhi's growth. As the development authority takes shape, two things happen. First, there is a fair degree of land acquisition and eminent domain. Second, almost all private development in the city comes to a halt. Delhi's major developers, who had constructed colonies through the south of the city, were no longer allowed to build. Instead, the DDA amassed more than 50,000 acres of land for its various construction and redevelopment projects (McKinsey, 2201; Wikipedia, 2020c).

The entire city is taken over as a public project. Their vision is to create an imperial capital. Revamping the state level machinery for urban development is even more crucial than at the central level. At present responsibilities of urban development are fragmented into different departments (McKinsey, 2001).

\section{The Success and Failure}

Rapid urbanization has earned the city the dubious distinction of being one of the most polluted in the world. Five decades after its first masterplan, the DDA was waxing poetically about its accomplishments in its 2006/07 annual report: In the 50 years of its efforts to maintain the pace of development and match steps with the best cities of the present era. On the other hand, even to the most casual observer, that report is a masterpiece of magical thinking (Wikipedia, 2020c).

Delhi today is the site of frenzied urbanization. Skyscrapers, malls, and gated communities sprout from farmland on the city's eastern edge. Trucks flow from highways into factories along its north. Throughout, new informal settlements continue to crop up, housing roughly half of Delhi's 18 million residents (McKinzey, 2001; Wikipedia, 2020c).

The DDA remains largely blind to these changes. At DDA headquarters, Nehru's urban planning apparatus remains intact. Bureaucrats shuffle through long, dark hallways. Stacks of rotting files line hallways and closets; triplicate traces of decades-old applications. They thought that they are building a world-class city by coming out with the Masterplan 2021. It promises to make Delhi a global metropolis: a center of IT innovation, green parks, and new high-rise housing (DDA, 2017; Wikipedia, 2020c).

Modern Delhi was born of this contrast - great vision, and little implementation. From the outset, Delhi's planners have imagined a vibrant capital city with ordered growth and universal housing. Yet in doing so, they planned for a city that did not exist, and they left the city's actual residents without proper planning (McKinzey, 2001; Wikipedia, 2020c).

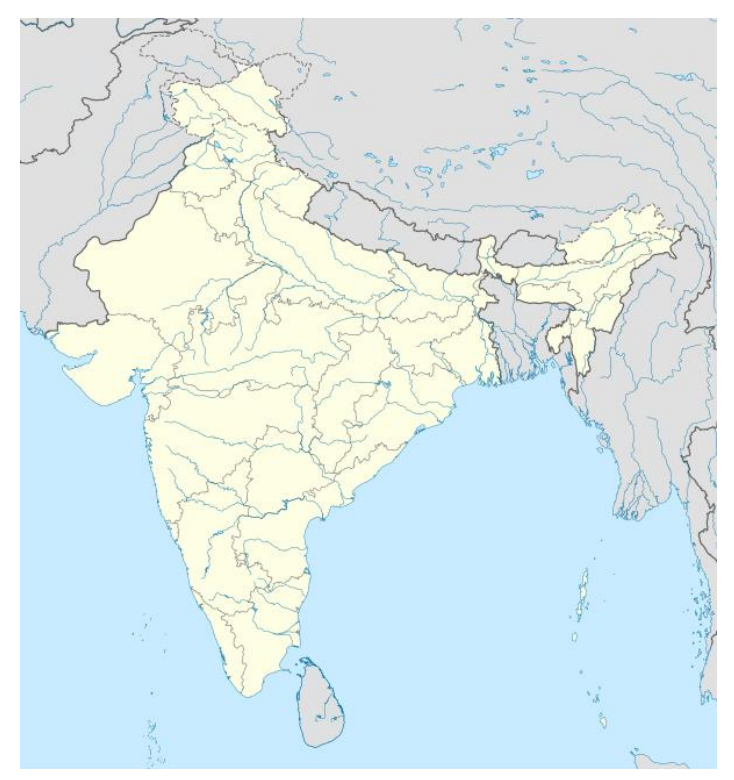

Figure 2. India 


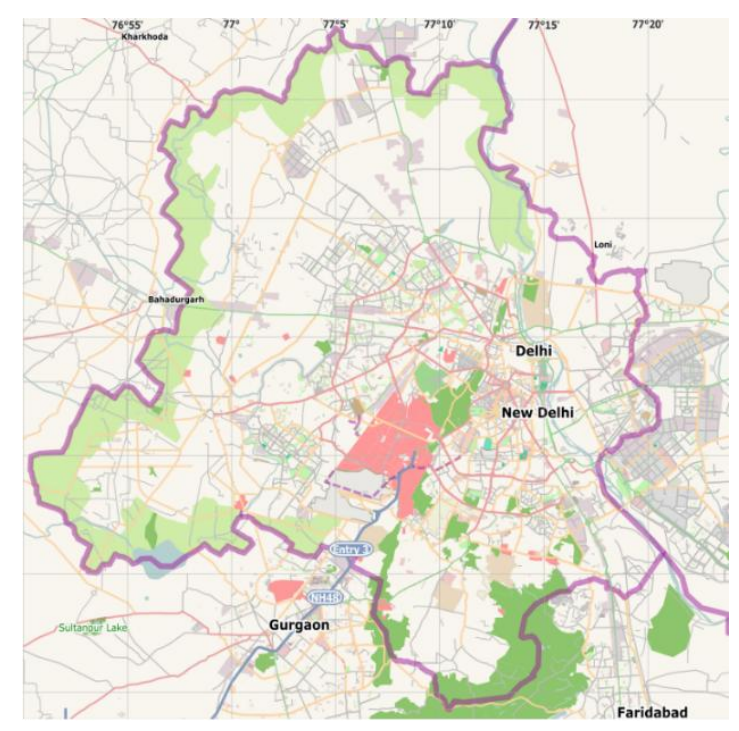

Figure 3. New Delhi

\section{Canberra (Australia)}

\section{The Reason}

Canberra was established in 1913 as a way of defusing the intense rivalry between Melbourne and Sydney. Situated inland to guard against a possible naval bombardment, Canberra is now home to Parliament House and the High Court of Australia as well as the head offices of all federal government departments and the military (Wikipedia, 2020d).

\section{The City Today}

Canberra is located within Australia Capital Territory (ACT). It is the largest inland city and the $8^{\text {th }}$ largest overall city in Australia. Canberra City is in the northern end of ACT, 290 $\mathrm{km}$ south of Sidney, and $660 \mathrm{~km}$ north of Melbourne (Wikipedia, 2020d).

As a new capital of Australia, this city very planned city from nothing. The road network is very specific has a very geometric network. The Central Wards are equipped with a big Lake Griffith. It consists mainly of several wheels and spoke structure. As part of the ACT, which mainly consists of forests, the Canberra is a very green city. A very green and quiet city, with an area of 814.2 sq.km. With a population, in 2019, of 426,704 persons, the city has a density of merely 503 people/sqkm, the annual growth is merely 1.5\%/year (Wikipedia, 2020d).

As the capital, Canberra is the seats for the Government, the Parliament, the High Court, the Governor-General, the Embassy, other important national offices, and the International Body. As the capital Canberra is furnish with several important higher education institutions: Australian National University (ANU), University of Canberra (UC), Canberra Institute of Technology (CIT), Royal Military College (RMC) Duntroon, and Australian Defence Force Academy. Canberra is also the center of Cultural Objects. Canberra is the location of Australia War Museum, Royal Australia Mint, National Gallery, National Museum, National Portrait Gallery, National Library, National Film and Sound Archives (Wikipedia 2020d).

In terms of transport, urban public transport is served by city-bus and a tramway line. While.interurban transports are served by intercity bus, train, airplane, and toll-road (Wikipedia, 2020d).

\section{The Success and Failure}

The city of Canberra function well as the Capital of Australia. Canberra is well connected to all States Capital, Brisbane, Sidney, Melbourne, Hobart, Adelaide, Perth, and Darwin, by air transport. Rail transport and also freeway connects the Canberra to Sidney and Melbourne. The population can be maintained relatively low, with a vast green area, pollution and traffic jam 
can not be found. Tramway has been built several years ago. The direct international flight connects Canberra with Singapore and Dubai.

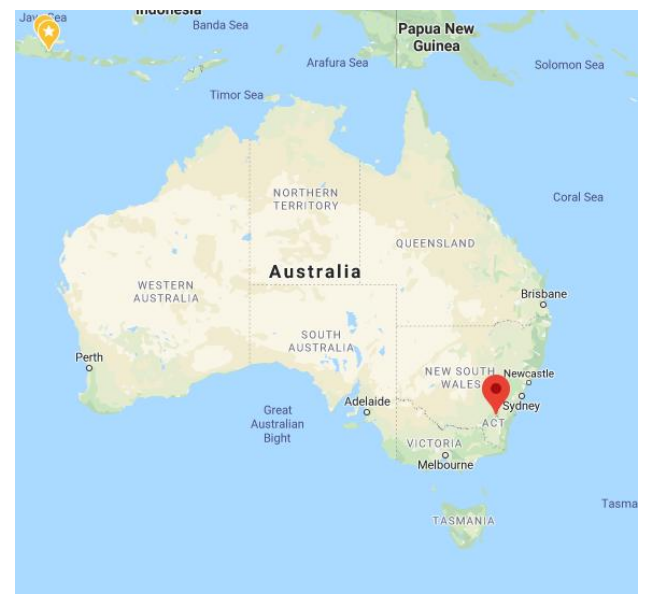

Figure 4. Australia

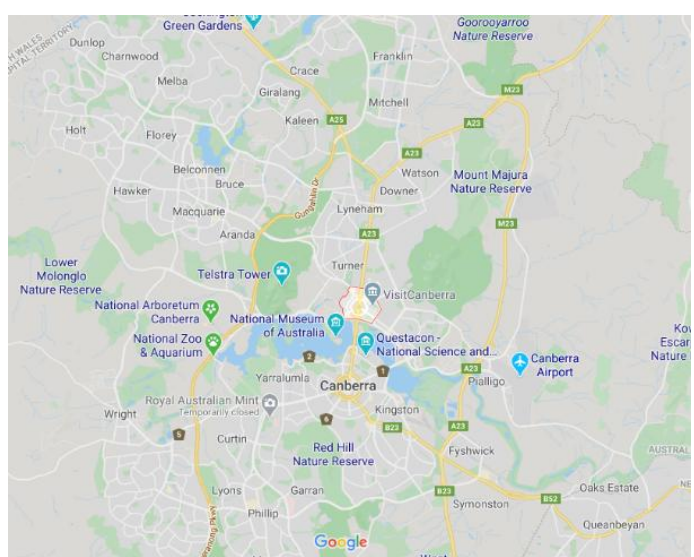

Figure 5. Australian Capital Territory - Canberra

\section{Islamabad (Pakistan)}

The southern port city of Karachi was named Pakistan's first capital in 1947 after the country gained independence from Britain. But in the 1950s, a group led by Field Marshal Mohammad Ayub Khan took control of the country in a coup and selected Islamabad in the north as the new capital. The site was chosen due to its proximity to the disputed territory of Kashmir and its invulnerability to coastal attacks (Wikipedia, 2020e).

Islamabad, a new capital of Pakistan was conceived in 1959, planned from 1959 to 1963 by a Greek architect-planner C. A. Doxiadis, and started implementation in 1961. The site was selected by a process of scientific search tempered by political considerations (Botka, 1995). The center of gravity, network connection such as existing Grand Truck (GT) Road, and proposed United Nations Trans-Asian Highway and topographical conditions such as a foothill of the Himalayas from 1600-1900 ft. above sea level was considered the main factor for selecting the site for Islamabad. Additionally, the site was selected by its proximity to the existing urban area of Rawalpindi. Rawalpindi helped in the development of Islamabad by providing access to the existing transport network, supplying labor for the development, and accommodating early inhabitant (UNDP, 2002; CDA, 1993).

\section{The Reason}

There are many opponents of the creation of Islamabad on a fact that Pakistan cannot afford such a luxury (Pott 1964; Meier 1985). Pott (1964) argued that a country that has so few natural resources of wealth and where 80 percent of the population is illiterate, huge expenditure 
on Islamabad was unnecessary. Meier (1985) explained that Islamabad drains so much capital from the economy of the whole country as happened in Brasilia and Chandigarh.

However, the creation of Islamabad is more economical rather than investing in Karachi for functional use as capital. He justified his approach by calculating per square ft. expenditure for the creation of Islamabad and the existing capital of Karachi. Additionally, Doxiadis had designed Islamabad in such a way that Pakistan could afford this city by proposing a laborintensive approach for construction. This approach slowed the pace of construction for Islamabad as big construction machinery was banned. Similarly, it was argued that the new capital of Pakistan should represent all cultural and social groups in Pakistan (Wikipedia, 2020e)

All functions of the federal government were moved to Islamabad, except for the central bank, which remains in Karachi, the country's main business hub. The Karachi Stock Exchange also remains the main bourse, overshadowing its counterpart in Islamabad (Wikipedia, 2020e).

\section{The City Today}

Federally administered as part of Islamabad Capital Territory (ICT), Islamabad a new city is located right next to Rawalpindi the existing city. The local government is run by Islamabad Metropolitan Corporation. Islamabad is the $9^{\text {th }}$ largest city in Pakistan, while the Islamabad Rawalpindi Metropolitan is the $4^{\text {th }}$ largest city of approximately 7.4 million of habitats. Islamabad is a planned city in created in 1960 with high standard living, a good safety, and abundant greeneries (Botka, 1995; Wikipedia, 2020e).

The population of Islamabad has swollen to about one million from less than 100,000 at the time of its creation. Complaints are often heard of higher rents and land prices, as well as the lack of public transport in the city, which was designed for cars. From the last three decades, economic growth accelerated due to the development of private housing schemes. However, physically integrated but institutionally disintegrated cities could not match the pace of rapid urban development. The implementation of the Master Plans for Islamabad and Rawalpindi prepared by C.A. Doxiadis in 1960, presents a complex picture of achievement and failure (Antonopoulus-Bogdanous, 2003; Dioxiadis, 1990).

The original Master Plan for Islamabad was based on an outstanding urban design by considering the whole metropolitan area. The plan was rigid as well as flexible in nature and well implemented in the new urban areas of Islamabad. However, the plan fails to accommodate the existing urban area of Rawalpindi. CDA implements the plan easily in vacant areas but fails to implement the plan where a complex situation arises with Rawalpindi. The decision for building Islamabad close to the existing city of Rawalpindi was a very wise one. Similarly, to incorporate the urban area of Rawalpindi in the Master Plan for Islamabad is relevant today as well. These decisions immediately helped Islamabad to better start. However, due to the absence of proper institutional arrangement, the original Master Plan has become weak and problems have gradually appeared (Husain, 1984).

As the Master Plan is developed by a Greek Architect: Constantinos Apostela Dioxiados, Islamabad is divided into 8 zones: administrative, diplomatic, residential, educations, industrial, commercial, rural \& green. ICT has several parks, including the vast Magalla Hills National Park and Shakarparian Park (Wikipedia, 2020e).

Islamabad, having an area of $220 \mathrm{~km}^{2}$, in elevation of $490-620 \mathrm{~m}$, has a population of $1,0134,825$ people, with a density of 2,089 people $/ \mathrm{km}^{2}$. While the Metropolitan has an area of $906.5 \mathrm{~km}^{2}$, with a population of 7,412,205 inhabitants. Islamabad has the highest cost of living (Wikipedia, 2020e).

Islamabad is the most developed city in Pakistan, with a Medium Human Development Index (HDI) of 0.678, the highest in Pakistan. It has a Life Expectancy of 70.77, higher than the average. It has a GRP/capita of \$ 8527, the highest in Pakistan. The population is dominated 
by the middle and upper-middle groups. It is the home of 20 universities, included Bahria University and Quaid-e-Azam University (Wikipedia, 2020e).

\section{The Success and Failure}

The original plan of Islamabad was overambitious - attempting to accommodate the urban area of Rawalpindi. The plan was weak to develop the institutional framework necessary to deal with the whole metropolitan areas. Overall metropolitan planning should be the responsibility of one organization. However, many organizations in three hierarchal government orders were responsible to implement the original Master Plan for Islamabad. In the hierarchy, CDA under the Federal Government was well equipped with technical people and finance to deal with the spirit of planning for Islamabad. On the other hand, Rawalpindi Municipal Corporation, Rawalpindi Development Authority (RDA), Rawalpindi Cantonment Board, Zila Council, and Rawalpindi City District Government were inadequate technical and financial resources to implement the Master Plan of Islamabad on the existing urban areas of Rawalpindi. No proper coordination mechanism developed to fulfill the objectives of the original planning. In reality, all organizations are working in their planning and policy guidelines (Frantzeskakis, 1985; Frantzeskakis, 2009; Maria \& Imran, 2006).

Islamabad absorbed the lion's share of resources for development. On the other hand, Rawalpindi received much fewer resources and developed a very low level of service standards. Moreover, Rawalpindi had continuously absorbed a huge overspill of low-income government servants which could not accommodate in Islamabad or could not bear the cost of living in Islamabad. Due to these imbalances of resources, the urban area of Rawalpindi was developed with ineffective land use planning and control. The lack of a proper institutional framework is creating a major barrier to attract further private investment in the housing sector for the Islamabad-Rawalpindi metropolitan areas. It is well recognized that planning is no more responsibility for the public sector alone. Planning can only be successful by the involvement of the private sector and community groups. The need for coordination of all these sectors at the metropolitan and regional scale has become imperative (Dogar, 1985; Maria \& Imran, 2008).

What is needed today is to establish a Metropolitan Development Authority by merging CDA and different authorities in Rawalpindi to receive a high level of resources and professional staff to meet the challenge of twin cities. In the long term, orderly and complementary growth of twin cities can only be ensured within the framework of a metropolitan organization, despite all legal and planning difficulties involved in such an approach. In the short term, the development of coordination mechanisms between authorities of both cities and formulating new and similar planning standards for private housing development can be adopted (Frantzeskakis, 1985; Frantzeskakis, 2009).

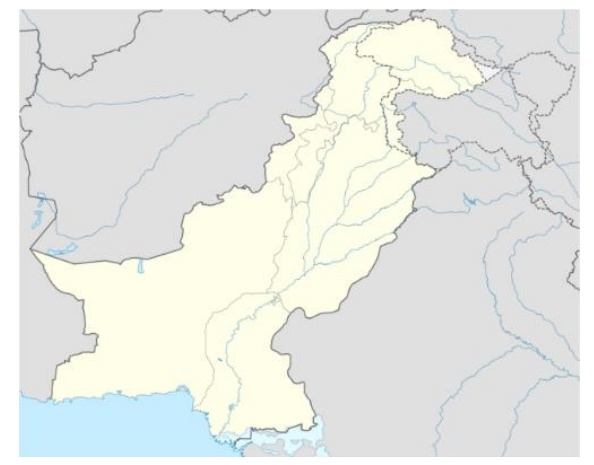

Figure 6. Map of Pakistan 


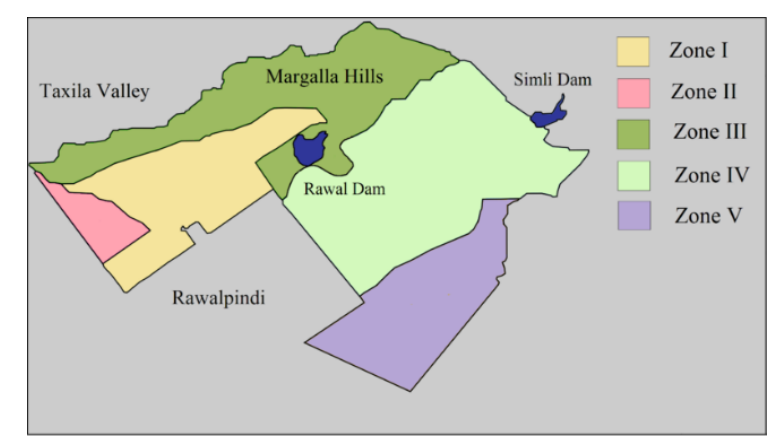

Figure 7. Map of Islamabad

\section{Putrajaya (Malaysia)}

The idea for the establishment of the Malaysian Government Administrative Centre away from Kuala Lumpur was mooted since the 1980s. Malaysia's then- (and current) Prime Minister Mahathir Mohamad proposed to move the nation's administrative capital from Kuala Lumpur in 1993, picking a site $25 \mathrm{~km}$ south of Kuala Lumpur. Putrajaya was named after the country's first prime minister, Tunku Abdul Rahman Putra al-Haj, and the entire project was designed and built by Malaysian companies for an estimated $\$ 8.1$ billion. Putrajaya, composed on a total area of 4581 hectares (around 13,700 acres), is located in a region where not too long ago was an agricultural area with a natural hill and a large swamp area that ran along the north-south axis. This wetland zone was converted into a magnificent man-made lake that divides Putrajaya into two major areas: The core Area and the Peripheral Area. The arrangements of transportation systems and zoning are based on the natural topography of the natural hilly site (Chin, 2006; Moser, 2010; Wikipedia, 2020f).

\section{The Reason}

One of the main rationales for moving the administrative center away from Kuala Lumpur was to ensure a quality urban living and environment for the new administrative center. The moving of the administrative functions of the Federal Government away from the already congested capital city not only helped to relieve the pressure on its overstretched infrastructure but also resolved the great shortage of Government land to cater for increased demand for office space. By establishing a new administrative center at a new site, the opportunities to have a well-planned urban center with modern facilities and technology to enhance Government efficiency and productivity were boundless (Chin, 2006; Moser, 2010; Wikipedia, 2020f).

While Kuala Lumpur remained as the country's financial and commercial capital, Putrajaya became the seat of government. Federal ministries and government agencies began moving there in 2003, the same year Mahathir stepped down as prime minister (Wikipedia, 2020f).

Almost all government bodies, including the prime minister's office and official residence, are now in Putrajaya. The city's development also included housing and leisure facilities and opened up office space while unlocking areas for private-sector development, helping the greater Kuala Lumpur region turn into a hub for global businesses (Moser, 2010; Putrajaya Corporation, 2013; Wikipedia, 2020f).

\section{The City Today}

Putrajaya city is a massive Government initiative due to its investment and scale. The 5,000 hectares is large enough to house a critical mass population of about 350,000 (and a daytime population of half a million. Since it is Greenfield site, the natural ecology of the site can be used as a large tract of greenery to ensure the implementation of the garden city concept where landscaping and water bodies are prominent components of the city. The Government vision is to for a City that reflects the natural and cultural heritage of the country and with the 
technological capacity incorporating the latest amenities to meet the challenges of the next millennium (Chin, 2006; Moser, 2010; Wikipedia, 2020f).

The planning of the adjacent Cyberjaya provided opportunities for the incorporation of the latest technology including the concept of an intelligent city. The infrastructure and utility planning also showcased the state of the art technology such as the use of an Intelligent Transport System, Gas district cooling system, Common Utility Trench, and the innovation of the creation of the largest manmade wetland as filtration for the Putrajaya Lake (Chin, 2006).

\section{The Success and Failure}

Putrajaya is planned with urban quality of life in mind. The use of neighborhood planning concept and caring society idea help to promote community integration and solidarity in a multiethnic Malaysian community. A total of 67,000 landed homes, apartments, and condominiums are built, with 3.8 million sq $\mathrm{m}$ of Government and 3.4 million sq $\mathrm{m}$ of commercial land uses in eight (8) precincts provide a shorter journey to work as workplaces and homes are located within the vicinity. With comprehensive planning of recreational and open spaces, its residents can enjoy a diverse range of entertainment, sports, and leisure and recreation activities, both indoor and outdoor. It is also a city with a clear identity and character rooted in local culture and tradition as evidenced by its local architecture and design. It shows how the ideas of garden city and intelligent city are translated on the ground. Putrajaya is an excellent showcase for a city for an administrative center for the new millennium (Chin, 2006; Moser, 2010).

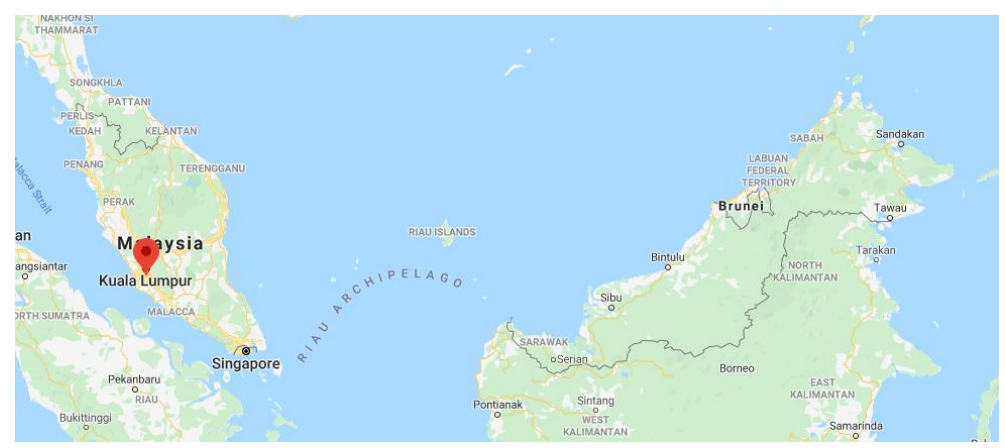

Figure 8. Malaysia

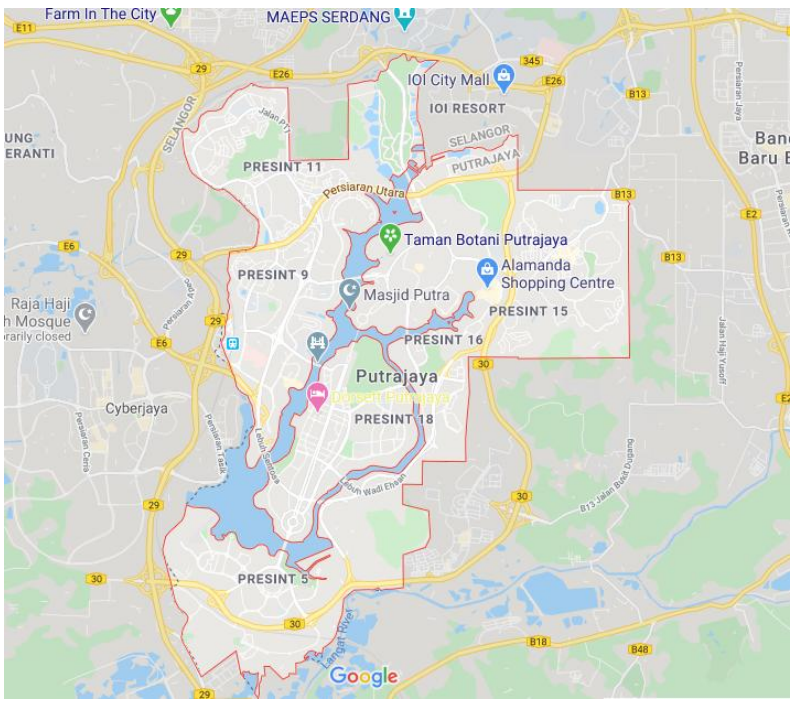

Figure 9. Putra Jaya 


\section{Nur-Sultan (Kazakhstan)}

Nur-Sultan used to be called Astana. It was renamed on March 232019 in honor of former President Nursultan Nazarbayev, who had stepped down only a few days earlier. The once drab previously the provincial settlement of Tselinograd, with a crumbling Soviet housing stock has been transformed into a vibrant modern city and the country's economic center, boasting $79 \%$ of the Kakazh population (Wikipedia, 2020g).

\section{The Reason}

Former President Nursultan Nazarbayev in 1994 pushed a law through parliament to move the capital from Almaty, which had been eclipsed by Uzbekistan's Tashkent as the Soviet Union's unofficial capital of Central Asia, to Akmola. The city was renamed Astana in 1998. Situated in the center of the country closer to oil production sites, Nur-Sultan is thought to have been chosen to increase the number of ethnic Kazakhs in the surrounding region at a time when it was feared that some provinces might break away and join Russia. However, the official reason for relocating to Astana was Almaty's location in an earthquake-prone region. But its proximity to the Chinese border and Kazakhstan's need to strengthen its hold on the north of the country with its large number of ethnic Russians made it logical from a strategic point of view. In this regard, the comparison with Ukraine is instructive: both have high Russian populations (Arslan 2014; Gawęcki, 2013; Wikipedia 2020g)

\section{The City Today}

Nur-Sultan's population in March 2020 is 1,144,755 habitants, in an area of $810.2 \mathrm{~km}^{2}$. The city was equipped with good education, health, commercial sport and recreation facilities. Nur-Sultan, started form a Master Plan developed by Kisho Kurokawa, it grows rapidly, and now become one of the most modern cities in Central Asia. All central government bodies have now moved to the city, which was again renamed Nur-Sultan when Nazarbayev stepped down in March. The central bank is the only remaining government body in Almaty (Wikipedia, 2020g).

The city has a prominent economic activity, i.e. trade, industrial product, transport, communication, construction. The main industrial products fabricated here are building material, foodstuff, and mechanics products. The city accommodates the head office of several biggest main state-owned companies in telecommunication, bank, gas, oil, and the others. In merely 16 years the economy grew 30 times in terms of investment, 90 times in terms of the GRP, 11 times in terms of industrial input $11 x$. The city produces a GRP of $8.5 \%$ of the nation (Wikipedia, 2020g).

UNESCO Has awarded Nur-Sultan as the City of Peace. Nur-Sultan is considered among the top 20 intelligent community. It is also among the Top Ten in CIS - Commonwealth Independent State. The World Expo 2017 was held in this city, under a theme of Future Energy, with very modern architecture (Wikipedia, 2020g).

The 22-kilometer elevated LRT line was supposed to connect the airport with a new train station. Along the way, it was to go through the EXPO exhibition area and Abu Dhabi Plaza, the tallest and the most expensive building in Kazakhstan. The LRT project was estimated to cost $\$ 1.9$ billion to build. In 2015, Beijing's state-owned China Development Bank agreed to provide that amount in the form of a long-term loan, and Chinese companies were supposed to do the work. Construction had been scheduled to end by 2017, the year in which Kazakhstan was hosting the EXPO. Due to financial difficulties, the project only began in 2017 with the plan of finishing by 2019. Finally, now the LRT Project is postponed again for an uncertain time, waits until the demand will meet the financial capacity (Wikipedia, 2020g).

Temperatures in Nur-Sultan can plummet to as low as minus 50 degrees Celsius (minus 58 degrees Fahrenheit). While apartments are connected to a central heating system. Using gas for the central heater is important. In November, Nazarbayev announced the start of the 
construction of the Saryarka gas pipeline, which was to carry the gas to northern regions of the country, including to Nur-Sultan. Around 1.7 million people in 171 villages and cities live along the route were to benefit from the project. However, project completion had been postponed many times (Wikipedia, 2020g).

Recently, Astana prepares the Integrated Water Management system and the Energy Efficiency Program, supported by the Asian Development Bank and the World Bank (ADB, 2018; ESMAP, 2017),

The Success and Failure

Astana rapidly becomes a very modern city. World Expo 2017 was held in Nur-Sultan. Nur-Sultan has successfully unified various Kazhaks ethnic groups into one unity of Kazakhstan. Urban facilities have been well developed, among others: the greenery, education, health facilities, urban public transport (Asrlan, 2014; Gawęcki, 2013). But, it must be noted also that certain facility developments had been postponed, due to the financial problem. A more careful development plan needs to be conducted.

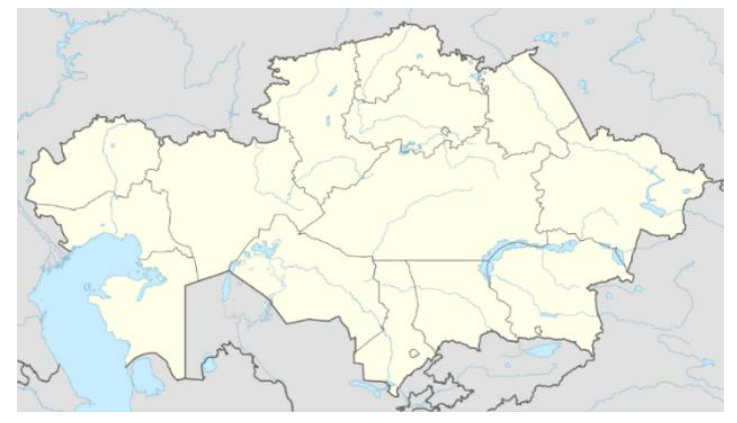

Figure 10. Kazakhstan

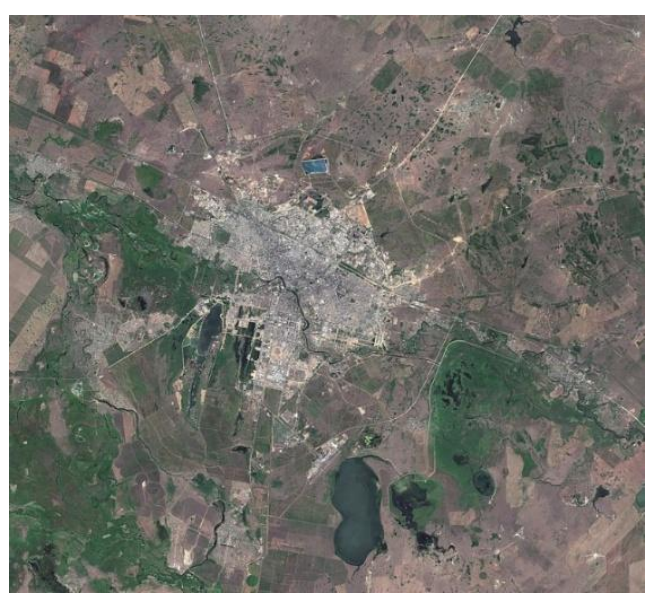

Figure 11. Astana

\section{Naypyidaw (Myanmar)}

\section{$\underline{\text { The Reason }}$}

Wary of a growing pro-democracy movement, Myanmar's junta government decided in 2001 to relocate the capital from coastal Yangon to centrally located Naypyidaw. The construction of the city was completed in 2005, and all government functions were swiftly transferred there by the following year. The reason why the site was chosen was various. Some say it was part of a military strategy, to stabilize the chronic turbulence region. The other reason says that the new location is a transportation hub, climate consideration, and the old capital to dense and too congested (Wikipedia, 2020h). 
As a new capital of Myanmar, Naypyidaw is still very low in population, even if the city size is very large. The city consists of a downtown surrounded by 8 townships. The downtown is divided into 4 wards. The City is managed by NPTDC - Naypiydaw Development Center. The territory is called as NUT - Naypiydew Union Territory, and become the capital since the year 2006 (Wikipedia, 2020h).

Naypyidaw is the seat for the Union Parliament, the Supreme Court, the Presidential Palace, and the Cabinet of Myanmar. Government offices are spread out across the sprawling, the empty city is known for its 20-lane highways. Several high-end hotels accommodate government guests and businesspeople, who fly into a modern but little-used airport that opened in 2011 (Wikipedia, 2020h).

Intercity transportation is served by Naypyidaw International Airport $16 \mathrm{~km}$ out of the city, and the Yangon-Napiydew Expressway (Wikipedia, 2020h).

The economic condition of Naypiedew is among the best in Myanmar, highest average income or revenue, least unemployment. In Naypiydew we can find enough education facilities, since elementary school up to higher education. Some vocational schools are also available. Healthcare service is also enough (Dobermann, 2015; Khaing, 2015).

\section{The Success and Failure}

Government officials living there tend to leave their families in Yangon due to the lack of commercial and educational facilities in the capital, even if those facilities are available. Most diplomats and foreign businesses also remain tied to Yangon, although the government of Aung San Suu Kyi is encouraging embassies to move to Naypyidaw. So far, however, only China has opened a liaison office there, with the U.S. to follow next year (Wikipedia, 2020h).

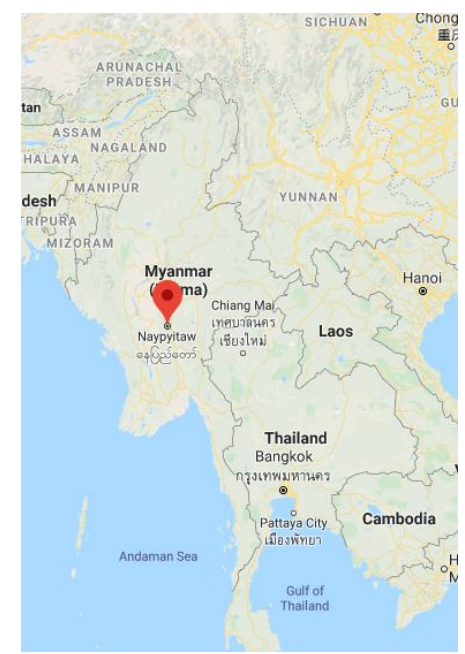

Figure 12. Myanmar

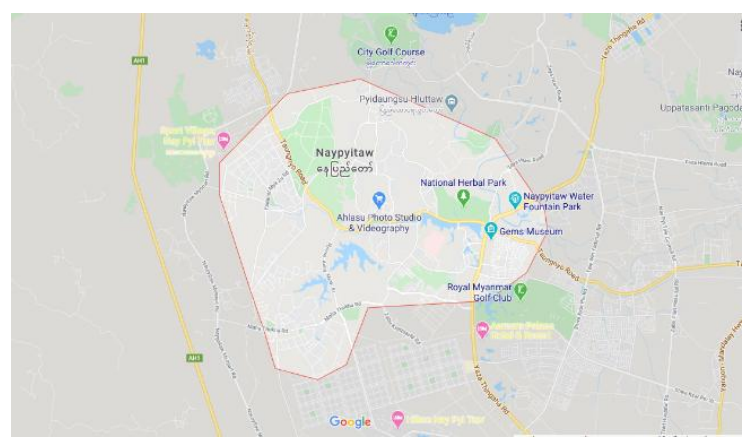

Figure 13. Naypyidaw 


\section{Synthese}

The brief desk observation of 6 National Capital Relocations has been done. This can be synthesized as follows.

- The common reason to relocate the capital are the old capital is already to dense and it is difficult to be developed, to balance the development among the different region. Political and military reasons are also the cause. Avoiding natural disaster regions can also be found as a reason.

- In general, the Success of capital relocation is due to good planning, good control of development, so that urban structure and density can be controlled. A good and adequate daily commercial, education health, communication, leisure, and transportation facilities are very much needed,

- Another hand, in general, Failure is due to a lack of good urban planning without a good development controlled. This, in general, cause rapid urbanization causing traffic jam and pollution. High residential housing and without mass transit and lack of daily needs commercial education, health, and leisure facilities.

\section{CONCLUSIONS}

Finally, the research has been well finished, and it produces principal conclusions as follows.

- Nation capital relocations have done by several countries throughout the $20^{\text {th }}$ century. So it is not an uncommon task.

- The main reasons for relocations are the former capital were already too dense, they were not efficient for capital function, for security reason, and for balancing development among different parts of the country.

- Good urban planning and design are needed.

- Good Urban Development control is an obligation.

- Daily needs facilities are vital: education, hospital, mall, public transport, leisure, sport.

- Excellent Green is needed, in the form of a large garden area and the vast wood area around the capital.

- Urban facilities' development must be planned carefully. Consideration between the needs and financial capacity must be well studied.

This research also contributes to explore the institutional aspect required to meet the new challenge of planning in the twenty-first century. This discussion will help to the made conclusion that without developing institutions, the best planning cannot be successful. The research will make a significant contribution to institutional planning according to the emerging demand from the private sector.

This research leads to several further curiosity, such as investigating more in-detail urban structure of certain capital, the principal consideration for choosing a new location for the new national capital, the good urban plan and design for the new capital, the stages and time needed for relocating the capital, the principal problems of capital relocation, the main infrastructure and facility asset management problem related to the capital relocation, a deeper observation of several new capitals.

Notes. This paper is a result of a reflection collaboration between a Malaysian Architect and an Indonesian Civil Engineer. This paper is the first paper toward a series of paper for developing a Basic Systematic Reflection on national capital relocation, from Infrastructure \& Facility Asset Management.

\section{REFERENCES}

ADB (2018). Republic of Kazakhstan: Astana Integrated Water Master Plan. Technical Assitance Report 2018. Asian Development Bank.

Anonim (2019). "Balikpapan - Samarinda Toll Road Progress Reach 97.4\%". IDN Financials, 22 October 2019, www.idnfinancials.com. 
Anonim (2020). "Jokowi minta Tol Balikpapan - Samarinda disambungkan dengan ibu kota baru". Kontan.co.id, 24 Januari 2020, https://regional.kontan.co.id.

Antonopoulus-Bogdanou, Myrto (2003). Research: City of the Future. Constantinos A. Doxiadis - Architect and Urban Planner. Athena

Ardiyanto, Wahyu (2020). "Kenali Para Pemenang Sayembara Lomba Disain Ibu Kota Negara". Liputan 6, 6 Januari 2020, www.liputan6.com.

Arslan, Mehmet (2014). "The significance of shifting the capital of Kazakstan from Almaty to Astana: An evaluation based on geopolitical and demographic developments". Procedia - Social and Behavioral Science - 120 (2014) 98-109.

Augesti, Afra (2019). "Brasil hingga Malaysia, 7 Negara yang Berhasil Meindahkan Ibu Kota". Liputan 6, 31 Juli 2019, www.liputan6.com.

Botka, D. (1995). "Islamabad after 33 years". Ekistics, 62, pp.209-235.

CDA (1993). "Modalities \& Procedures: Framed under ICT Zoning Regulations, 1992”. Capital Development Authority. Islamabad.

Chin Shiong Ho (2006). "Putrajaya Administrative Centre of Malaysia Planning Concept and Implementation". Sustainable Urban Development and Governance Conference Conference, Seoul, 16 November 2006. Sun Kyung Kwan University. Seoul, Korea.

DDA (2017). Master Plan for Delhi - 2021. Delhi Development Authority. New Delhi.

Dobermann, Tim (2015). Urban: Myanmar. Policy Notes - November 2016. International Growth Center.

Dogar, N. (1985), 'The Twin City of Islamabad/Rawalpindi: An Evaluative Study of TwentyFive Years of Plan Implementation', unpublished M.Sc. thesis, Asian Institute of Technology, Bangkok.

Doxiadis, C.A. (1990). Projects: Islamabad the Capital of Pakistan. Constantinos A. Doxiadis - Architect and Urban Planner. Athena.

Elena, Maria (2019). "PUPR Targetkan Pembangunan Jembatan Pulau Balang II Selesai Akhir 2020". Bisnis.com, 7 Desember 2019, https://ekonomi.bisnis.com.

ESMAP (2017). Municipal Energy Efficiency Plan for the City of Astana. ESMAP - Energy Sector Management Assitance Plan, World Bank.

Frantzeskakis, J. (1995), "Configuration, Hierarchy, and Spacing of the Urban Road Network in Islamabad”. Ekistics, 62, pp.236-241.

Frantzeskakis, I.M. (2009), "Islamabad, a town planning example for a sustainable city". Sustainable Development and Planning IV, Vol. 1, 2009.

Gawęcki, Marek (2013). "New urbanization of the steppe: A capital call the capital". Studia Historiae Oeconomicae, Vol. 31, January 2013.

Husain, I. (1984), 'Raising Resources for Development', in, Burki, S. and La Porte. R. (Eds.), Pakistan's Development Priorities: Choices for the Future, Karachi: Oxford University Press, pp.103-136.

Khaing, Thin Thin (2015). "Urbanization: The Structure of Sustainable Urban Landscape of Myanmar". International Conference on Burma/Myanmar Studies - 2015. Chiang Mai University.

Klein, Christopher (2018). "8 Forgotten Capitals of the United States". History, August 22, 2018, www.history.com.

McKinsey (2001). India-From emerging to surging. 2001. McKinsey \& Company. (available at http://www.Mckinsey)

Maria, S.I. \& Imran, M. (2006) "Planning of Islamabad and Rawalpindi: What went wrong?" $42^{\text {nd }}$ ISoCaRP Congress. Istambul. Turkey.

Meier, R. (1985). "Islamabad is already Twenty-Five". Ekistics, May/June, pp.212-216. 
Mohan, Rakesh (1985). "Urbanization in India's Future". Population and Development Review, 11, (4). New York: Population Council. 1985. --- "Housing and Urban Development: Policy Issues for the 1990s".

Moser, Sarah (2010). "Putrajaya: Malaysia's new federal administrative capital". Cities; The International Journal of Urban Policy and Planning, 27 (2010) : 285-297.

Pott, J. (1964). "Impressions of Islamabad - West Pakistan". Housing Review, 13(3), pp.49-52.

Putrajaya Corporation (2013). Toward Putrajaya Green City 2025. Putrajaya Corporation. Putrajaya. Malaysia.

Sawe, Benyamin Elisha (2019). "What is the Capital of Japan".World Atlas, August 21, 2019, www.worldatlas.com.

Soemitro, R.A.A. \& Suprayitno, H. (2018). "Pemikiran Awal tentang Konsep Dasar Manajemen Aset Fasilitas". Jurnal Manajemen Aset Infrastruktur \& Fasilitas, Vol. 2, Suplemen 1, Juni 2018, Hal. : 1-14.

Suprayitno, H. \& Soemitro, R.A.A. (2019). "Preliminary Reflexion on Basic Principle of Infrastructure Asset Management". Jurnal Manajemen Aset Infrastruktur \& Fasilitas, Vol.2, No. 1, Maret 2018, Hal. : 1-10.

UNDP (2002), "Katchi Abadis and Some Viable Alternatives: A Case Study and Operational Guidelines based on the Capital Development Authority, Islamabad's Approach 1998 to 2000”. United Nations Development Program. Islamabad.

Wikipedia (2020). "List of Purpose-Built National Capitals". Wikipedia, https//:en.wikipedia.org/wiki/List_of_purpose-built_national_capitals.

Wikipedia (2020a). "Thailand". Wikipedia, https//:en.wikipedia.org/wiki/Thailand.

Wikipedia (2020b). "Province of Canada". Wikipedia, https//:en.wikipedia.org/wiki/Province_of_Canada.

Wikipedia (2020c). "New Delhi”. Wikipedia, https//en.wikipedia.org/wiki/New Delhi.

Wikipedia (2020d). "Canberra". Wikipedia, https//en.wikipedia.org/wiki/Canberra.

Wikipedia (2020e). "Islamabad". Wikipedia, https//en.wikipedia.org/wiki/Islamabad.

Wikipedia (2020f). "Putrajaya". Wikipedia, https//:en.wikipedia.org/wiki/Putrajaya.

Wikipedia (2020g). "Nur-Sultan”. Wikipedia, https//en.wikipedia.org/wiki/Nur-Sultan.

Wikipedia (2020h). "Naypiydaw". Wikipedia, https//:en.wikipedia.org/wiki/Naypiydaw.

Wikipedia Indonesia (2020). "Bandar Udara di Kalimantan Timur". Wikipedia Indonesia, https://id.wikipedia.org.

Wikipedia Indonesia (2020a). "Daftar Perguruan Tinggi Negeri di Kalimantan Timur". Wikipedia Indonesia, https://id.wikipedia.org. 